Journal of History Culture and Art Research (ISSN: 2147-0626)

Tarih Kültür ve Sanat Araştırmaları Dergisi

Vol. 8, No. 4, December 2019

\title{
DOI: 10.7596/taksad.v8i4.2238
}

Citation: Karatekin, K., Akcaoğlu, M. Ö., \& Taban, M. H. (2019). A Comparative Study on Multicultural Attitude of University Students: Austria, Hungary and Turkey Sample. Journal of History Culture and Art Research, 8(4), 36-55. doi:http://dx.doi.org/10.7596/taksad.v8i4.2238

\section{A Comparative Study on Multicultural Attitude of University Students: Austria, Hungary and Turkey Sample}

\author{
Kadir Karatekin ${ }^{1}$, Mustafa Öztürk Akcaoğlu' ${ }^{2}$, Muhammed Hayati Taban ${ }^{3}$
}

\begin{abstract}
Increasing diversity within European countries has led the policy makers and the public to question the place of immigrants in society. Classrooms are becoming multicultural growingly as the migrants increase and mobility among countries becomes easier. Moreover, the number of diversities and cultural differences brought by the refugee students have raised. To this end, in this study, we aim to reveal and compare the multicultural attitudes of university students studying in different countries. A total of 356 university students from Turkey, Austria and Hungary participated in the study. In order to collect data, The Munroe Multicultural Attitude Scale Questionnaire (MASQUE) was used. The results revealed that there is a significant difference among the countries in terms of multicultural attitude, gender and political views of the participants. According to the findings, while Austria has the highest score in terms of multicultural attitude, Hungary has the lowest score. In addition, Austrian university students have the highest total score of multicultural attitude and know sub-dimension while Turkish university students have the highest scores of care and act sub-dimensions. Furthermore, it can be said that living/studying in an EU member country does not necessarily mean that university students have a high level of multicultural attitude.
\end{abstract}

Keywords: Multicultural attitude, university students, multiculturalism, diversities

\footnotetext{
${ }^{1}$ Prof.Dr., Kastamonu University, E-mail: kadirkaratekin@gmail.com

${ }^{2}$ Assist. Prof. Dr., Kastamonu University, E-mail: ozturk@kastamonu.edu.tr

${ }^{3}$ Lecturer, Kastamonu University, E-mail: htaban@kastamonu.edu.tr
} 


\section{Introduction}

One of the critical questions in the grand sweep of human history from China and India, through the Hellenic, Roman, Ottoman, and European empires was to ascertain how communities with cultural differences could uncover the ways to live together in harmony (Berry \& Sam, 2014). However, with the advent of easy and fast means of transportation and communication, diverse qualifications regarding culture, religion, language and some other elements have increased to an unprecedented level in modern societies. These diversities can be thought as agents for integration or as a means to create conflict and disintegration in society. Therefore, it is important how individuals perceive "others" and what can be done to shape people's ideas towards a synthesis within same borders. To this end, multiculturalism can serve as a crucial tool to bridge among individuals and societies.

According to Banks (2010, p. 474) multiculturalism is "A philosophical position and movement that assumes that the gender, ethnic, racial, and cultural diversity of a pluralistic society should be reflected in all of the institutionalized structures of educational institutions, including the staff, the norms and values, the curriculum and the students body." Because of its scope, multiculturalism is regarded as one of the most important concepts of the academia in the $21^{\text {st }}$ century. Some researchers consider the term as a notion about the integration of diversities in a society and some others view it as "the end of European dominance, a balkanization of heritage and legacy at the expense of time-honored western traditions" (Trotman, 2002, p. ix).

Since the end of Cold War and the foundation of European Union (EU), there has been a drive towards integration and promotion of cultural differences. Especially after the acceptance of immigrants on a large scale, some of the European countries started to question if there is a need for control of immigration and laws to assimilate the minorities. At this point, some politicians are still debating about the goal of equality and cannot agree on whether it should be acquired through assimilation, integration or multiculturalism (Lesińska, 2014; Verloo, 2006). Despite these discussions about the concept of multiculturalism, most of the politicians accepted that the idea of a multicultural society and creating a multicultural Europe is regarded as a cornerstone (Zemni \& Parker, 2002). Because of this, there is an urgent need to discuss and implement multicultural reformist actions because the population of Europe has become more diverse.

The migration flux, termed as European migrant crisis or the European refugee crisis, towards the EU countries started in 2015 and the number of people arriving through the Mediterranean Sea has increased (Clayton, 2015). United Nations High Commissioner for Refugees (UNHCR) reported that there were 1,000,000 asylum applications only for Syrian refugees in the European Union in 2017 and 538000 asylum seekers were granted protection status in the Member States of the EU in 2017 (UNHCR, 2018). Depending on the political views and the views of general public, the number of vary a great deal among the member countries and Turkey stands out in ranking as a candidate country. The two countries, Austria and Hungary, where the data for this study were collected have not accepted asylum since 2012; however, Turkey accepted 228.889 refugees from Syria only in 2017 and there are more than 3.5 million Syrian refugees as of October, 2018 (Mülteciler Derneği, 2018; UNHCR, 2018). There is a striking contrast with respect to the figures among these countries. Regarding the concept of multiculturalism, despite the term championed by the European countries before Turkey, 
it is observed that many European countries follow abstaining or ridicule policies about the different cultural elements brought by immigrants.

The perspectives of above-mentioned EU countries with regards asylum seekers have become stricter. Austria declared that the number of asylum applications was confined to 37.500 on January 20th, 2016 and 80 applications per day on February 19th, 2016 (BBC, 2016). Furthermore, the country projected penalties for the applicants who refuse to leave (Deutsche Welle, 2017). On the other hand, Hungary also rejects and blocks asylum seekers and views them as threats to security and culture (Thorpe, 2015). In 2016, soldiers were deployed to the borders under a state of emergency and it was extended till March 2019 (Kafkadesk, 2018). Contrary to the government policies, universities in both countries are open to host students with diverse backgrounds.

\section{Multicultural Education in EU Context}

Increasing diversity within European countries has led the policy makers and public to question the place of immigrants in society. The debates generally revolve around assimilation on one side and multiculturalism on the other side (Bloemraad, I., Korteweg, A., \& Yurdakul, G, 2008; Harles, J. C., 1997; Modood, T., 2011) However, there is a clear understanding that embracing diversities and seeking ways to live in harmony can create a healthy society in the long term. To this end, all the institutions, especially institutions of higher education, that form a nation should play an active role, and adopt a multicultural curriculum which is an important step towards the creating of a multicultural society.

Classrooms are becoming multicultural growingly as the migrants increase and mobility among countries becomes easier. Moreover, the number of diversities and cultural differences brought by the students have raised after the civil wars and unrest in Middle East countries and Africa (Ahmad, 2018). Because of this, millions of school-aged migrants have been moving to European countries to access better living conditions. Schools act as agents of change and play a crucial role in developing multicultural consciousness. To this end, the importance of multicultural education was recognized to some extent in the three countries, where the data for this study were gathered.

Austria has a formal multicultural education program and the relations between cultures have been an important component of the curriculum since 1992, but the idea behind multicultural education reform is not clearly reflected in the educational system (Mitchell \& Salsbury, 1996; Queen's University, 2011). Despite Austria's long history of refugee movements, educational system is still passive in terms of multicultural approaches and the Austrian school system still persists in a single language of instruction and regards the school environment as homogeneous (Atanasoska \& Proyer, 2018; Queen's University, 2011). It can be said that multicultural education is ignored and the students with diversities are expected to adapt to the monolingual and monocultural school system (Fürstenau \& Gomolla, 2011). However, when a large number of refugees arrived in the country, especially after 2015, the classrooms have become increasingly heterogeneous in terms of culture, language, race, ethnicity, etc. (Krüger-Potratz, 2004). Neglecting the other cultural elements, diverging from multicultural education and expecting diverse populations to adapt and behave in line with the dominant cultural elements is apt to cause inequalities regarding the school achievement. Hofer, Skrivanek, and Tomic (2015) assert that in Austria students with a migrant background have poor school performance and are less likely to continue their education. Furthermore, teacher training programmes do not offer multicultural 
education certifications and the focus of curriculum is assimilation except for some special programmes (Mitchell \& Salsbury, 1996).

As of Hungary, Cartwright, Sik, and Svensson (2008) state that the country is a mono-ethnic country with a low level of diverse population. Accordingly, the citizens of Hungary do not identify their country as multicultural (Spinthourakis, Lalor \& Berg, 2011a). The society perceives the acceptance of diversities as a threat to their national identity and associates the idea of integration with social problems (Cartwright et al., 2008). The prevailing idea regarding the multicultural issues among the individuals is also reflected in the field of education. According to Spinthourakis et al. (2011a), in Hungary, the first thing that comes to the mind of anyone talking about multicultural education is national education; furthermore, in the school system there is a remarkable degree of segregation and split. In addition, the number of standardized multicultural practices is limited and teachers either coin new methods or inclined to devalue the insults (Marton, 2001). There are also severe problems in terms of academic achievement and equality. The students who cannot fully grasp Hungarian are seen as low achievers and placed in classes well below their age (Cartwright et al., 2008). Therefore, one can conclude that there is a long way in Hungary to achieve multicultural education reform.

In terms of the diversities, Turkey, a candidate country for EU since 1999, is no different from EU member countries. Especially the ongoing turmoil in the Middle East and after the Syrian civil war, Turkey has become a shelter for the refugees, which multiplied the existing multicultural structure of the country. Especially, about 1.7 million school-age children, 616.000 of whom are enrolled at schools (Unicef Türkiye Milli Komitesi, 2018), created problems with regard to methodologies, materials, attitudes and beliefs at educational institutions. According to the results of a report, a language other than Turkish is spoken in the houses of $51.9 \%$ of the students who drop out of school (Gökşen, Cemalcılar, \& Gürlesel, 2008). The changes in the curricula and teacher training system cannot keep up with the dramatically growing number of diverse population. Aydın (2012) asserts that in Turkey there is a need to determine the aims, goals and processes of educational policies in line with cultural diversities and social tolerance. When curricula of faculties of education and institutes of educational sciences are examined, it can be observed that only six of 114 state funded universities have a theoretical course on multicultural education (Akcaoğlu \& Arsal, 2018). The results of research studies also revealed that Turkey has not even reached the level of awareness in terms of multicultural education (Demir, 2012).

\section{Multiculturalism and Ideologies}

Ideologies are one of the key factors on people's defining their stance against life. Naturally, attitude towards others, in this case multiculturalism, is also shaped by ideologies. For example, those holding liberal values are expected to have different attitude than those holding conservative or nationalistic political view. At this point, understanding briefly what liberalism, conservatism, socialism and nationalism say about multiculturalism will help to analyze participants' attitude better.

Liberalism is an ideology based on the principles of freedom, equality, limited power, consent, constitutionality, rationality and individualism (Taşkın, 2014). Therefore, considering the emphasis placed on the individual and the equality, it is expected that people holding liberal political view tend to have a high understanding of multiculturalism. Indeed, the distinctive feature of liberal social ethics 
is the desire to accept the moral, cultural and political difference and, in some cases, to exalt them. Tolerance as one of the foundations of liberal thought emerged in the 17th century with the aim to defending religious freedom by liberal writers John Milton and John Locke (Heywood, 2013). In the 21st century, a wider liberal understanding of the freedom of religion has emerged in almost every field (ethnic, linguistic, etc.).

Simply explained, conservatism is based on the protection of the tradition. The defense of the tradition, which is one of the basic principles of conservatism, causes it to distance itself from multiculturalism. The tradition in this context encompasses the values, practices and identities that can withstand time, and in particular from one generation to the next. The lack of trust in human rationality and the nature of man's moral degeneration lead conservatives to approach the issue of multiculturalism with a sense of suspect. As conservatives see the society as an organic form, multiculturalism is considered to be a threat to this organic structure, so it is considered to be a deterioration of the structure (Heywood, 2013). Therefore, conservative people tend to be against meeting multicultural expectations.

Socialism emphasizes that it is important to understand the society in which the individual lives to understand the individual. In other words, individuals learn all the skills and qualities from the society. Thus, individuals can understand themselves and be understood by the social groups they belong to. Socialists believe that liberalism must be transcended in terms of equality of opportunity and all structural inequalities must be eliminated to achieve full equality (Heywood, 2013). As a matter of fact, the only difference that is rejected in socialist thought and needs to be eliminated is the class difference. In this sense socialist thought approach multiculturalism in a positive manner believing that the diversities among cultures should be supported.

The nation, the organic community, self-determination and identity politics are the main pillars of nationalism. The ideology of nationalism, which began with the process of nation building in Europe in the 19th century and peaked with anti-colonial struggles after World War II, is one of the most remote ideologies to multiculturalism. Forming a nation is one of the main points of the ideology of nationalism. According to Heywood (2013) language, religion, ethnic/racial unity, common history and cultural unity are the elements that make up the nation. All forms of nationalism without exception are directly related to the issue of identity. At this point, besides the political goals, the ideology of nationalism imposes on people who they are (Turan, 2017). Nationalism, while it has different practices in different countries, is far more distant from other approaches to a multiculturalist understanding.

\section{Present Study}

Cultural diversity, as is the case in almost all countries, is also an observable phenomenon in Europe where it hard to find a society with mono-cultural features, such as same traditions, values, language, food, etc. Especially after the Free Movement and Schengen Agreement, mobility and cultural exchanges have increased dramatically. As a result, although Europe is accepted as a unifying region, it has become more heterogeneous and multiculturalism has become a heatedly debated political topic (Sprague-Jones, 2011). Therefore, one of the most important missions of $21^{\text {st }}$ century is to find out ways to live together in harmony in a multicultural society. 
The results of the change regarding the demographic structure are felt in all spheres of life, specifically in educational institutions. The system of education has to organize its structure according to the diversities and act as a model for society (Spinthourakis, Lalor, \& Berg, 2011b). It is a fact that an average university in Europe hosts academic staff and students with diverse qualifications in terms of culture, religion, sexual preferences and so on. These differences mirror the globalization of the world and signal an urgent requirement for multicultural education in higher education (McCray, Wright, \& Beachum, 2004). As explained by Banks (2010), multicultural education is to be viewed as "an idea, an educational reform movement, and a process whose major goal is to change the structure of educational institutions" (p. 1). In order to find out what countries do to integrate multiculturalism in university curricula and how it affects the students' thoughts, there is a need to reveal and compare the attitudes of university students studying in different countries. To this end, we aim to find possible answers to the following research questions;

1. Is there a significant difference between the multicultural attitude levels (know, care, act) of Turkish, Hungarian and Austrian university students?

2. Do Turkish, Hungarian and Austrian university students' multicultural attitudes towards differ by gender?

3. Do Turkish, Hungarian and Austrian university students' multicultural attitudes differ by political view?

\section{Method}

\section{Research Design and Sample}

In this quantitative study, survey research design was used to compare the level of multicultural attitudes of Turkish, Austrian and Hungarian university students. Survey is used by social scientists to produce statistics about some aspects of the study population by asking questions and to empirically and scientifically study and provide information about people and social phenomena and it can be used to find out the opinions, attitudes, and behaviors of persons and to obtain other factual information about members of this population (Groves et al., 2011).

The population of the study consisted of randomly-selected university students enrolled in the universities in Ankara, Turkey; Vienna, Austria and; Budapest, Hungary. The participants' profile is presented in Table 1.

Table 1: Gender distribution of participants by country

\begin{tabular}{llll}
\hline Country & Gender & $f$ & $\%$ \\
\hline \multirow{3}{*}{ Turkey } & Male & 78 & 21.9 \\
\cline { 2 - 4 } & Female & 278 & 78.1 \\
\cline { 2 - 4 } & Total & 356 & 100.0 \\
\hline \multirow{3}{*}{ Hungary } & Male & 59 & 33.3 \\
\cline { 2 - 4 } & Female & 118 & 66.7 \\
\cline { 2 - 4 } & Total & 177 & 100.0 \\
\hline \multirow{3}{*}{ Austria } & Male & 51 & 27.7 \\
\cline { 2 - 4 } & Female & 133 & 72.3 \\
\cline { 2 - 4 } & Total & 184 & 100.0 \\
\hline
\end{tabular}


When Table 1 is examined, it can be observed that a total of 356 university students, $21.9 \%$ of whom male and $78.1 \%$ of whom female, from Turkey; 184 university students, $27.7 \%$ of whom male and $72.3 \%$ of whom female, from Austria and; 177 university students, 33.3 of whom male and $66.7 \%$ of whom female, from Hungary participated in the study.

\subsection{Instrumentation}

The Munroe Multicultural Attitude Scale Questionnaire (MASQUE) developed by Munroe and Pearson (2006) was used to determine and compare the level of multicultural attitudes of Turkish, Austrian and Hungarian students. The scale was used in its original form, English.

MASQUE, which was developed based on Banks transformative approach, aims to measure participants' multicultural attitudes. During the development process, exploratory factor analysis was conducted and the results revealed 18 items and three subscales: know, care and act. The first factor explained $16.89 \%$, the second factor $15.33 \%$, and the third factor $14.44 \%$ of the total variance (Munroe \& Pearson, 2006). Know dimension is about knowledge of attitudes regarding cognitive thoughts, beliefs, perceptions related to and objects. Care includes an assessment of multicultural attitudes either positive or negative. The last dimension Act means specific actions concerning intercultural issues, feelings and objects. Participants respond to 18 items using a Likert-type scale ranging from 1 (strongly disagree) to 6 (strongly agree). Internal consistency reliability for the whole scale was calculated as $\alpha=.80$; as for the subscales $\alpha=.70$ for Know $\alpha=.70$ for Care and $\alpha=.58$ for Act was calculated. Validity data on the measure indicates it has adequate content and discriminant validity (Munroe \& Pearson, 2006). The researchers recommended that the scale be used as a whole because of the low reliability of the last subscale. MASQUE has been extensively used in different cultures to determine the level of multicultural attitudes (Enger \& Lajimodiere, 2011; Kim, 2014; Polat \& Barka, 2012; Tinkler, Hannah, Tinkler, \& Miller, 2014; Uttley, 2008; Weiler, Helfrich, Palermo, \& Zimmerman, 2013). The average scores of participants regarding the level of multicultural attitude were interpreted based on the following intervals:

$1-1.80-$ completely negative

1.81-2.64 - negative

$2.65-3.48-$ partially negative

$3.49-4.32-$ partially positive

$4.33-5.16-$ positive

$5.17-6.00-$ completely positive

\subsection{Data Analysis}

The level of candidate teachers' attitude towards multiculturalism and intercultural education were determined by performing descriptive statistics. In addition, whether candidate teachers' level of attitude change according to their gender, departments and universities was tested through t-tests and; bivariate correlation analysis was conducted to test whether there is a relation between candidate teachers' attitude towards multiculturalism and intercultural education. Finally, one-way ANOVA was conducted to find out whether there is a significant difference among the participants in terms of their political views. Before conducting ANOVA, the assumptions of the analysis (normality, sample independence and variance equality) were checked and it was observed that the data met the requirements. 


\subsection{Procedures}

The demographic questions and the scale were administered to the university students enrolled in different universities in Turkey, Austria and Hungary during the breaks at the campus area. Prior to the administration, the participants were informed about the nature and purpose of the study and they were told that the study aims at revealing their multicultural attitudes. In addition, the researchers informed the students that their responses to the surveys would remain anonymous.

\section{Findings}

This section aims to summarize some preliminary analysis and findings. Before understanding the results of the study, it will be helpful to remember some crucial descriptive statistics regarding to participants and their answers. At this point descriptive statistics of the participants regarding Know, Care and Act sub-dimensions, results of descriptive analysis related to the participants' political view and their answers to each item in the scale are presented below.

Table 2: Descriptive statistics regarding Know, Care and Act Sub-dimensions

\begin{tabular}{|c|c|c|c|c|c|c|c|c|c|}
\hline & \multicolumn{3}{|c|}{ Turkey } & \multicolumn{3}{|c|}{ Hungary } & \multicolumn{3}{|c|}{ Austria } \\
\hline & $\mathrm{n}$ & $\bar{X}$ & Sd & $\mathrm{n}$ & $\bar{X}$ & Sd & $\mathrm{n}$ & $\bar{X}$ & Sd \\
\hline Know & 356 & 5.02 & .73 & 177 & 5.03 & .71 & 184 & 5.47 & .53 \\
\hline Care & 356 & 5.11 & .69 & 177 & 4.16 & .95 & 184 & 4.81 & .91 \\
\hline Act & 356 & 4.54 & .86 & 177 & 3.70 & .79 & 184 & 4.40 & .79 \\
\hline Multicultural Attitude & 356 & 4.92 & .58 & 177 & 4.37 & .61 & 184 & 4.95 & .53 \\
\hline
\end{tabular}

Table 2 reveals the results of descriptive analysis based on the sub-dimensions. When each subdimension was analyzed individually it can be observed that in Turkey, the highest average $(\bar{X}=5.11)$ belongs to the care sub-dimension, followed by know sub-dimension ( $\bar{X}=5.02)$ and act sub-dimension $(\bar{X}=4.54)$.

Given that the averages were between 4.33-5.16, we can say that Turkish university students have positive multicultural attitude regarding each sub-dimension and the scale as a whole. The results of descriptive statistics of Turkish participants also show that the highest standard deviation score belongs to act sub-dimension and the lowest one belongs to care sub-dimension. These results show that the level of care and know of Turkish participants are similar while they have differences in act sub-dimension. On the other hand, data collected from Hungary participants show positive and partially positive results for the sub-dimensions. When each sub-dimension was analyzed individually for Hungary, the highest average ( $\bar{X}=5.03$ ) belongs to the know sub-dimension, followed by care subdimension $(\bar{X}=4.16)$ and act sub-dimension $(\bar{X}=3.70)$.

Given that averages were between $4.33-5.16$ shows a positive attitude, it can be asserted that Hungarian participants have a positive multicultural attitude for know sub-dimension and the total score, and a partially positive attitude for care and act sub-dimensions. Descriptive statistics of Hungarian participants also show that the highest standard deviation score belongs to care subdimension and the lowest one belongs to know sub-dimension. These results show that the level of act and know of Hungarian participants are similar while they have differences in care sub-dimension. Based on the results, it can be summarized that the attitude of Hungarian participants towards multiculturalism is positive and partially positive. 
It is also seen from Table 2 that participants from Austria show completely positive and close to positive results for three sub-dimensions. When each sub-dimension was analyzed individually, it was observed that the highest average $(\bar{X}=5.47)$ belongs to the know sub-dimension, followed by care $(\bar{X}=4.81)$ and act sub-dimensions $(\bar{X}=4.40)$.

Given that averages were between 4.33-5.16, the results suggest that the participants from Austria have a positive multicultural attitude for all sub-dimensions and the scale as a whole. Descriptive statistics of Austrian participants also show that the highest standard deviation score belongs to care sub-dimension and the lowest one belongs to know sub-dimension.

These results show that the level of act and know of Austrian participants are similar while they have differences in care sub-dimension.

Table 3: Descriptive results of the participants according to political view

\begin{tabular}{lccccccccc}
\hline \multirow{2}{*}{ Political view } & \multicolumn{3}{c}{ Turkey } & \multicolumn{4}{c}{ Hungary } & \multicolumn{3}{c}{ Austria } \\
\cline { 2 - 10 } & $\mathrm{n}$ & $\overline{\mathrm{X}}$ & $\mathrm{Sd}$ & $\mathrm{n}$ & $\overline{\mathrm{X}}$ & $\mathrm{Sd}$ & $\mathrm{n}$ & $\overline{\mathrm{X}}$ & $\mathrm{Sd}$ \\
\hline Liberal & 28 & 4.87 & .74 & 42 & 4.67 & .74 & 73 & 4.98 & .50 \\
\hline Conservative & 35 & 4.87 & .42 & 12 & 4.49 & .42 & 3 & 4.19 & .73 \\
\hline Socialist & 77 & 5.19 & .57 & 5 & 4.47 & .57 & 80 & 4.02 & .50 \\
\hline Nationalist & 89 & 4.75 & .57 & 5 & 3.72 & .57 & - & - & - \\
\hline Apolitical & 105 & 4.91 & .53 & 87 & 4.25 & .53 & 28 & 4.76 & .56 \\
\hline Other & 22 & 4.78 & .58 & 26 & 4.34 & .58 & - & - & - \\
\hline
\end{tabular}

Table 3 revealed that in Turkey $(n=105)$ and Hungary $(n=87)$, most of the participants had an apolitical view. The participants in Austria mostly adopted a socialist political view $(n=80)$. On the contrary, liberal point of view in Turkey ( $n=35)$, socialist and nationalist views in Hungary $(n=5)$ and nationalist $(n=0)$ and conservative $(n=3)$ views in Austria had the least supporters.

The results of descriptive analysis with regard to MASQUE are presented in Table 4.

Table 4: The results of descriptive analysis regarding each item of the MASQUE

\begin{tabular}{|c|c|c|c|c|c|c|c|c|c|c|}
\hline & \multirow[b]{2}{*}{ Items } & \multicolumn{3}{|c|}{ Turkey } & \multicolumn{3}{|c|}{ Hungary } & \multicolumn{3}{|c|}{ Austria } \\
\hline & & $\mathrm{n}$ & $\bar{x}$ & Sd & $\mathrm{n}$ & $\bar{X}$ & Sd & $\mathrm{n}$ & $\bar{x}$ & $\mathrm{Sd}$ \\
\hline \multirow{7}{*}{ Know } & 1. I realize that racism exists. & 356 & 4.94 & 1.40 & 177 & 5.33 & 1.03 & 184 & 5.66 & 0.79 \\
\hline & 2. I know that social barriers exist. & 356 & 5.09 & 1.10 & 177 & 5.09 & 1.02 & 184 & 5.62 & 0.70 \\
\hline & 3. I understand religious beliefs differ. & 356 & 5.28 & 1.10 & 177 & 5.09 & 1.10 & 184 & 5.40 & 0.97 \\
\hline & 4. I understand sexual preferences may differ. & 356 & 4.98 & 1.32 & 177 & 4.75 & 1.38 & 184 & 5.51 & 0.99 \\
\hline & 5. I understand that gender-based inequities exist. & 356 & 5.02 & 1.22 & 177 & 4.69 & 1.29 & 184 & 5.32 & 1.06 \\
\hline & $\begin{array}{l}\text { 6. I accept the fact that languages other than my own } \\
\text { language are spoken. }\end{array}$ & 356 & 5.04 & 1.32 & 177 & 5.57 & 0.88 & 184 & 5.88 & 0.49 \\
\hline & $\begin{array}{l}\text { 7. I do not understand why people of other cultures } \\
\text { act differently. }\end{array}$ & 356 & 4.78 & 1.56 & 177 & 4.72 & 1.48 & 184 & 4.91 & 1.43 \\
\hline
\end{tabular}


8. I am sensitive to respecting religious differences. $\begin{array}{llllllllll}356 & 5.37 & 0.97 & 177 & 4.19 & 1.62 & 184 & 4.55 & 1.53\end{array}$

9. I am sensitive to differing expressions of ethnicity. $\begin{array}{lllllllll}356 & 5.00 & 1.06 & 177 & 3.98 & 1.38 & 184 & 4.66 & 1.47\end{array}$ 10.I am emotionally concerned about racial $3564.92 \quad 1.30 \quad 177 \quad 4.00 \quad 1.43 \quad 184 \quad 4.90 \quad 1.24$ inequality.

Care

11.I am sensitive toward people of every financial status.

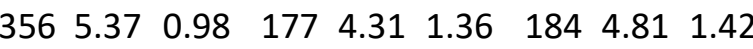

12.I am not sensitive to language uses other than my own language.

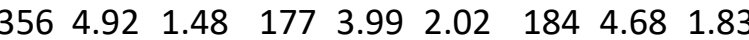

13.A person's social status does not affect how I care about people.

$\begin{array}{lllllllll}356 & 5.09 & 1.32 & 177 & 4.50 & 1.41 & 184 & 5.26 & 1.17\end{array}$

14.I do not act to stop racism.

$\begin{array}{lllllllll}356 & 4.73 & 1.41 & 177 & 3.82 & 1.41 & 184 & 4.52 & 1.20\end{array}$

$15 . I$ actively challenge gender inequities.

$\begin{array}{lllllllll}356 & 4.17 & 1.43 & 177 & 3.21 & 1.30 & 184 & 3.92 & 1.45\end{array}$

16.I do not actively respond to contest religious prejudice.

$\begin{array}{lllllllll}356 & 4.34 & 1.41 & 177 & 3.23 & 1.35 & 184 & 3.83 & 1.33\end{array}$

Act

17.I respectfully help others to offset language barriers that prevent communication.

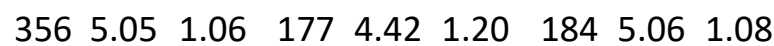

18.I do not take action when witnessing bias based on people's preferred sexual orientation.

$\begin{array}{lllllllll}356 & 4.41 & 1.41 & 177 & 3.82 & 1.37 & 184 & 4.67 & 1.32\end{array}$

In Table 4, we can see item average scores for each sub-dimension based on the nations. When the results from Turkey are examined, it can be observed that each item in the know sub-dimension is in the range of positive values $(4.33-5.16)$. In this sub-dimension, item 3 has the highest score $(\bar{X}=5.28)$, and item 7 has the lowest score $(\bar{X}=4.78)$. In the care sub-dimension, it is seen that the item averages are in the positive range. In this sub-dimension, item 8 and 11 have the highest scores $(\bar{X}=5.37)$, whereas item 10 and 12 have the lowest scores $(\bar{X}=4.92)$. Finally, it is observed that item averages are within the positive range in the act sub-dimension. In this sub-dimension, item 17 has the highest score $(\bar{X}=5.05)$ and item 15 has the lowest score $(\bar{X}=4.17)$.

For participants from Hungary, each item in the know sub-dimension is in the range of positive values. In this sub-dimension, item 6 has the highest score ( $\bar{X}=5.57)$, and item 5 has the lowest score $(\bar{X}=4.69)$. In the care sub-dimension, it is seen that the item averages are in the partially positive and positive range. In this sub-dimension, item 13 has the highest score $(\bar{X}=4.50)$, whereas item 9 has the lowest score $(\bar{X}=3.99)$. Finally, it is observed that item averages are within the partially negative and positive range in the act sub-dimension. In this sub-dimension item 17 has the highest score $(\bar{X}=4.42)$ and item 15 has the lowest average ( $\bar{X}=3.21)$.

Table 4 also reveals that each item in the know sub-dimension for the participants from Austria has positive values. In this sub-dimension, item 6 has the highest score $(\bar{X}=5.88)$, and item 5 has the lowest score $(\bar{X}=5.32)$. In the care sub-dimension, it is seen that the item averages are in the positive range. In this sub-dimension, item 13 has the highest score $(\bar{X}=5.26)$, whereas item 8 has the lowest scores $(\bar{X}=4.55)$. Finally, it is observed that item averages are within the partially negative and positive range in the act sub-dimension. In this sub-dimension, item 17 has the highest score ( $\bar{X}=5.06)$ and the item 15 has the lowest score $(\bar{X}=3.92)$. 
The findings regarding the research questions, which investigate the differences among participants from different countries in terms of multicultural attitude, gender and political view variables, will be revealed.

Table 5: One-way ANOVA results on whether there is a significant difference in multicultural attitude levels (know, care, act) of university students

\begin{tabular}{|c|c|c|c|c|c|c|c|}
\hline $\begin{array}{l}\text { Dependent } \\
\text { Variable }\end{array}$ & Source & sd & KT & KO & $\mathrm{F}$ & $p$ & $\begin{array}{c}\text { Difference } \\
\text { Scheffe }\end{array}$ \\
\hline \multirow{3}{*}{ Total Score } & $\begin{array}{l}\text { Between } \\
\text { groups }\end{array}$ & 2 & 41.23 & 20.61 & 62.58 & .00 & $\begin{array}{l}1-2^{*} \\
1-3^{*}\end{array}$ \\
\hline & In group & 714 & 235.19 & 0.33 & & & $2-3^{*}$ \\
\hline & Total & 716 & 276.42 & & & & \\
\hline \multirow{3}{*}{ Know } & $\begin{array}{l}\text { Between } \\
\text { groups }\end{array}$ & 2 & 27.35 & 13.68 & 29.60 & .00 & $\begin{array}{l}1-3^{*} \\
1-2^{*}\end{array}$ \\
\hline & In group & 714 & 329.96 & 0.46 & & & \\
\hline & Total & 716 & 357.31 & & & & \\
\hline \multirow{3}{*}{ Care } & $\begin{array}{l}\text { Between } \\
\text { groups }\end{array}$ & 2 & 105.76 & 52.88 & 78.71 & .00 & $\begin{array}{l}2-1^{*} \\
1-3^{*}\end{array}$ \\
\hline & In group & 714 & 479.68 & 0.67 & & & \\
\hline & Total & 716 & 585.44 & & & & \\
\hline \multirow{3}{*}{ Act } & $\begin{array}{l}\text { Between } \\
\text { groups }\end{array}$ & 2 & 85.96 & 42.98 & 63.33 & .00 & $\begin{array}{l}1-3^{*} \\
2-3^{*}\end{array}$ \\
\hline & In group & 714 & 484.56 & 0.26 & & & \\
\hline & Total & 716 & 570.52 & & & & \\
\hline
\end{tabular}

*1- Austria, 2- Turkey, 3- Hungary

According to the results of the study, the multicultural attitude levels of university students as a whole $[F(2-714)=62.58 ; p<.05]$, and in the sub-dimensions of know $[F(2-714)=29,60 ; p<.05)$, care [F (2$714)=78.71 ; p<.05)$ and act $[F(2-714)=63.33 ; p<.05]$ showed a significant difference in terms of the country. Scheffe test was carried out to understand to where the differences lie. According to the results, a significant difference was found between Turkish participants $(\bar{X}=4.92)$ and Hungarian participants $(\bar{X}=4.37)$ in terms of total score regarding multicultural attitude in favor of Turkish university students. In addition, a significant difference was found between Austrian participants ( $\bar{X}=4.95)$ and Hungarian participants $(\bar{X}=4.37)$ in terms of total score in favor of Austrian participants. When know sub-dimension was analyzed, a significant difference was found between Turkish participants $(\bar{X}=5.02)$, Hungarian participants $(\bar{X}=5.03)$ and Austrian participants $(\bar{X}=5.47)$ in favor of the Austrian university students.

The results of care sub-dimension also show that there is a significant difference between the Turkish participants $(\bar{X}=5.11)$ and Hungarian participants $(\bar{X}=4.16)$ in favor of Turkish university students. In addition, there is a significant difference between the Turkish participants $(\bar{X}=5.11)$ and Austrian ones $(\bar{X}=4.81)$ in favor of Turkish participants.

When it comes to act sub-dimension, the results show that there is a significant difference between Turkish participants $(\bar{X}=4.54)$ and Hungarian ones $(\bar{X}=3.70)$ in favor of Turkish participants. 
Furthermore, there is a significant difference between Austrian participants $(\bar{X}=4.40)$ and Hungarian ones $(\bar{X}=3.70)$ in favor of Austrian participants.

A paired sample t-test was carried out to find out whether university students' multicultural attitudes differ by gender.

Table 6: The Results of Independent Sample T-Test Regarding the Participants

\begin{tabular}{lllllll}
\hline Country & Gender & $\mathrm{n}$ & $\mathrm{SS}$ & $\overline{\mathrm{X}}$ & $\mathrm{t}$ & $\mathrm{p}$ \\
\hline \multirow{2}{*}{ Turkey } & Male & 78 & 0.64 & 4.71 & 3.54 & $.00^{*}$ \\
\cline { 2 - 5 } & Female & 278 & 0.55 & 4.97 & & \\
\hline \multirow{2}{*}{ Hungary } & Male & 59 & 0.60 & 4.17 & \multirow{2}{*}{3.14} & $.02^{*}$ \\
\cline { 2 - 5 } Austria & Female & 118 & 0.60 & 4.47 & & \\
\hline
\end{tabular}

${ }^{*} p<.05$

The results of Independent Samples T-test related to the data obtained from participants from Turkey show a significant difference in terms of gender. When Table 5 is examined, it can be seen that the mean scores of female students $(\bar{X}=4.97)$ are higher than the mean scores of female students $(\bar{X}=4.71)$ and this difference is significant $(p<.05)$. In addition, when the results from Hungary are examined, it can be seen that there is also a significant difference in terms of gender. The mean scores of female students $(\bar{X}=4.47)$ are higher than the mean scores of female students $(\bar{X}=4.17)$ and this difference is significant $(p<.05)$. On the contrary, the results of the analysis related to the participants from Austria showed that there is no significant difference in terms of gender. The mean scores of female students $(\bar{X}=4.99)$ are higher than the mean scores of female students $(\bar{X}=4.86)$ but this difference is not significant ( $p>05)$.

One-way ANOVA was carried out to find out whether university students' multicultural attitudes differ by their political views.

Table 7: The Results of One-way ANOVA regarding Turkish and Hungarian University Students' Multicultural Attitudes and Political Views

\begin{tabular}{|c|c|c|c|c|c|c|c|}
\hline Country & Source & sd & KT & KO & $\mathrm{F}$ & $\mathrm{P}$ & Difference Scheffe \\
\hline \multirow{3}{*}{ Turkey } & Between Groups & 5 & 8.93 & 1.79 & 5.71 & .000 & $3-4^{*}$ \\
\hline & Among Groups & 350 & 109.50 & 0.31 & & & \multirow{2}{*}{$3-5^{*}$} \\
\hline & Total & 355 & 118.43 & & & & \\
\hline \multirow{3}{*}{ Hungary } & Between Groups & 5 & 7.22 & 1.45 & 4.21 & .001 & $1-4^{*}$ \\
\hline & Among Groups & 171 & 58.71 & 0.34 & & & $1-5^{*}$ \\
\hline & Total & 176 & 65.93 & & & & \\
\hline
\end{tabular}

*1- Liberal, 2-Conservative, 3- Socialist, 4- Nationalist, 5- Apolitical, 6- Other Political View

According to the results, there is a significant difference in terms of political view $\left[F_{(5-350)=5.71 ; p<.05]}\right.$ in Turkey. Scheffe test was carried out to understand which groups have difference. It was observed that there is a significant difference between the mean score $(\bar{X}=5.19)$ of participants holding a socialist political view and those holding nationalist $(\bar{X}=4.75)$, political view, apolitical $(\bar{X}=4.91)$ and other political view $(\bar{X}=4.78)$ in favor of socialist political view. 
The analysis regarding the political views of Hungarian students revealed that there is a significant difference in terms of political view $\left[F_{(5-171)}=4.21 ; p<.05\right]$. When the results Scheffe test was examined, it was seen that there is a significant difference between the mean score $(\bar{X}=4.67)$ of participants holding a liberal political view and those holding nationalist $(\bar{X}=3.72)$, apolitical $(\bar{X}=4.25)$ political view in favor of liberal political view.

Table 8: The Results of One-way ANOVA regarding Austrian University Students' Multicultural Attitudes and Political Views

\begin{tabular}{llllllc}
\hline Source & sd & KT & KO & F & P & Difference Tukey HSD \\
\hline Between groups & 3 & 3.31 & 1.10 & 4.18 & .007 & \multirow{2}{*}{$1-3^{*}$} \\
\hline Among groups & 180 & 47.51 & 0.26 & & & \\
\hline Total & 183 & 52.82 & & & & \\
\hline
\end{tabular}

*1- Liberal, 2-Conservative, 3- Socialist, 4- Apolitical

According to the results of the analysis, there is a significant difference in terms of political view $[\mathrm{F}$ (3$180=4.18 ; p<.05$ ] with regard to the participants from Austria. Tukey HSD test was carried out to understand which specific groups' means are different. It was seen that there is a significant difference between the mean score $(\bar{X}=4.98)$ of participants holding a liberal political view and those holding socialist political view $(\bar{X}=4.02)$ in favor of the liberal political view.

\section{Discussion}

In this study, the findings revealed that the participants from Turkey and Austria had significantly higher levels of multicultural attitude levels when compared to Hungarian university students who have the lowest score in terms of total multicultural attitude scores and sub-dimensions. There can be more than one factor that explains this finding. In their study of the rise of the far-right in Hungary, Karácsony and Róna (2011) pointed out that far-right votes increased in response to the gypsies (Romans) who are most populous minority in the country. From this point onwards, the European economic crisis and the migration movements from the Middle East multiplied this effect and it was determined that the voters were directed to paternalistic and nationalist far-right parties in order to restore order. Furthermore, in Hungary, the youth unemployment rate is $10.8 \%$ and the GDP per capita is 14.840 USD (OECD, 2019c). As a matter of fact, the Hungarians define migration as the biggest problem of the EU and their countries in 2017, which is a proof that the situation has not improved. While the Hungarian people personally see the biggest problem as rising prices in the economy, $82 \%$ of the Hungarians see refugees as a burden on their own business and social benefits as a factor affecting their attitude towards multiculturalism. In addition, $76 \%$ of Hungarians (which is the highest in Europe) think that refugees will increase the likelihood of terrorism in their countries, fed by the tension experienced by the gypsy population in their countries, as well as for economic reasons (European Commission, 2018). According to the results of the same research, $41 \%$ of the Hungarians believe that the surplus of people of different races, ethnic groups and nationalities will make their country a worse place and $39 \%$ believe that it will not have any positive effect. Therefore, their view against migration from outside EU member states is $81 \%$ negative and they think that additional measures should be taken both in the country and in the EU in addition to the current situation and measures. In connection with these data, only $15 \%$ of the Hungarian people support the solution of cultural diversity and openness to other cultures in the solution of global problems. The Hungarian public sees the first thing that needs to be done for the future of Europe is to clearly draw the borders of the EU (EU average of 19\%). On the other hand, ethnic origin is the most common source of 
discrimination ( $3^{\text {rd }}$ rank with $63 \%$ percent among 27 EU countries) and ethnic origin or skin color will be the biggest disadvantage (64\% in all EU countries) (European Commission, 2018). In the elections held in 2014, the far-right parties with anti-immigrant and nationalist ideology reached the highest votes (FIDESZ-KDNP Party: $44.8 \%$ and Jobbik 20.2\%) (Szegő, 2019). The 65\% of the two far-right parties still provide an insight into Hungary's view of multiculturalism. To this end, we can assert that the statistical data and results of other studies support the findings of this study regarding the Hungarian participants.

However, it would be wrong to say that the election results and the spirit of time in Hungary are at the same rate among the youth. Because, our findings also showed that the mean score of Hungarian students are within the partially positive interval. One reason for this may result from the fact that more than half of the Hungarian participants are either liberal or apolitical. Also only 5 of the Hungarian participants define them nationalist, therefore; it is not surprising that Hungarian participants having liberal view have a high level of multicultural level.

Austria, in this study, was observed to have the highest mean score in terms of multicultural attitude in general and know sub-dimension of the scale. This finding means that Austrian students have a positive multicultural attitude. When the results regarding the Austrian university students were investigated, it was observed that there was a clash between Austrian university students and public view in terms of multiculturalism. Austria is one of the richest countries in Europe with a GDP per capita of $\$ 47.700$ but since the early 2000s, the youth unemployment rate has shown an increasing trend and especially after 2008 this increase has been dramatic (OECD, 2019a). By the end of 2017, the youth unemployment rate reached 9.5\% (OECD, 2019c). As a result of their research on populist right-wing movements in Europe and their constituents, Inglehart and Norris (2016) found that the rise of rightwing movements, the shocking effect of modernization and the development that came along with traditional values and the demographic structure of migrants from poor countries causes corruption. In other words, one of the factors that should be considered besides the economic factors in the rise of the rightist populist movements is a conflict between the values of the old generation and the cultural change brought about by the new era. Inglehart and Norris (2016) also found that those over the middle age, those with low educational level, tend to vote for populist right-wing parties that advocate cultural values, address nationalist sentiment, pursue xenophobia, pursue an alienation policy, and advocate old-head gender roles. Researchers, such as Zaslove (2004), are among those who find anti-immigration effective in raising these right-wing movements. Zaslove (2004) leads the fear of migrants in Austria to the influx of migrants from Eastern Europe following the dissolution of the Soviet Union. While not as much as Hungary, $34 \%$ of people in Austria believe that migration is the biggest problem of the EU and the country. Moreover, in terms of personal problems, the biggest problem of the Austrians has been identified as increasing prices. Accordingly, Austria is the farthest member for the view of the EU enlargement. $56 \%$ of Austrians are also negative for migration from outside the EU member states. In addition, the majority of Austrians (86\%) thinks that measures should be taken on irregular migration from outside the EU member states, both within the EU and country-specific, as well as existing measures on migration. In Austria, cultural diversity and openness to different cultures, which are among the solutions to be emphasized in solving global problems, are below the EU average with a rate of $17 \%$. Another opinion that supports this data is the belief that the Austrians should clearly draw the borders of the EU as the first measure for the future of Europe (the highest EU average with $42 \%) .53 \%$ of Austrians acknowledge that ethnicity and skin color negatively affect the likelihood of recruitment in terms of employment opportunities in their countries, which is well above the EU average of 39\%. The results of the October 2017 elections in Austria support the aforementioned data. 
With the anti-refugee and populist agendas, the Conservative People's Party (31.5\%) and the Rightwing Freedom Party (27\%) reached 58.5\% in total (Austrian Press \& Information Service in the United States, 2017).

Although it is difficult to say that the rising rightist movements in Austria cannot find a base among the youth, it can be said that at least the university youth are not ideologically right-weighted, they use reactive votes and can give up their preferences for those who vote for the right party. Our study also indicated that more than half of the Austrian participants have either liberal or apolitical political view. At this point, it is not surprising that those having liberal political view have a better multicultural level compared to other political views. Moreover, Austrian universities host 95,716 foreign students in the 2016/2017 winter term (OECD, 2019b; UNESCO Institute for Statistics, 2019). When this number is considered as proportional, it gives us that there are $27 \%$ foreign students in state universities and $42 \%$ in private universities.

Turkey, according to our results, has the second higher multicultural attitude score after Austria and in terms of act dimension, it has the highest score. It may seem surprising for a non-EU country to have high scores in terms of multiculturalism but recent reports and studies show the similar trend. In Turkey, especially with the start of EU accession negotiations, respect for differences has been adopted among young people in terms of multiculturalism. Some comparative research results of young people aged 15-29 between 2008 and 2018 found that young people adopted a multicultural environment and tended to be less conservative in addition to respect for differences (KONDA Araştırma ve Danışmanlık A.Ş. 2018). In the literature, multicultural studies seem to concentrate on multicultural perception/attitude and multicultural education. Damgacı and Aydın (2013), who conducted one of the studies on multiculturalism, analyzed the attitudes of Turkish academics on multicultural education by using the Multicultural Education Attitude Scale. As a result of their research, it was found out from the arithmetic average of the scores of academicians that their attitudes towards multicultural education were very high. Ünlü and Örten (2013) examined the perceptions of prospective teachers about multicultural education, using the case study model within the framework of qualitative research method. As a result of their research, it was determined that prospective teachers had both right and wrong propositions about the concepts of multiculturalism and multicultural education, and their attitude levels are positive and negative. In their study, Çoban, Karaman, and Doğan (2010) examined the prospective teachers' perspectives on cultural differences according to various demographic variables using the Opinions on Human Differences Questionnaire. According to the results of their studies, prospective teachers' perspectives towards cultural differences were positive. Özdemir and Dil (2013) examined the multicultural attitudes of teachers working in official high schools. In their research, they analyzed teachers' multicultural attitudes by using the Multicultural Attitude Scale in terms of some demographic variables. As a result of the research, the researchers found that participants' attitudes towards multicultural education were positive. The results of Turkish participants in terms of their political view also support these findings. Those holding socialist and liberal political view have higher scores compared to nationalistic politic view holders. Moreover, the total number of socialist and liberal political view is higher than conservative political view. What is surprising here is that the highest number in political view variable belong to apolitical view. However, apolitical view holders have the second highest multicultural attitude score.

The results of the study also revealed that female university students in Turkey and Hungary had significantly higher levels of multicultural attitude when compared to male students. In line with this finding, some other studies showed that there is a significant difference between the two sexes in favor of female participants (Miller-Whitehead, 2005; Pettus \& Allain, 1999; Turner, 2007). This 
perception might stem from female participants' emotional inclination (Briton \& Hall, 1995; Robinson \& Johnson, 1997; Timmers, Fischer, \& Manstead, 2003), ability for higher differentiation in terms of emotional experiences (Barrett, Lane, Sechrest, \& Schwartz, 2000). or their better empathy skills (Baron-Cohen \& Wheelwright, 2004; Davis, 2018). Because both Turkey and Hungary do not have a good level of gender equality situation opposite to Austria, those women may have a tendency to understand "others" better than men (United Nations, 2018). However, there are still some studies showing a significant difference in favor of male participants (McCray \& Beachum, 2010) or no difference (Breugelmans \& Van De Vijver, 2004; Nadelson et al., 2012; Schalk-Soekar \& Van de Vijver, 2008). Therefore, we cannot assert a conclusive result with regard to gender differences.

\section{Conclusion}

In modern world, as a result of the fast exchange of people and ideas, multiculturalism has been one of the phenomena that countries cannot escape. At this point each culture, that is to say every individual from different cultures/countries/backgrounds/origins have a different attitude towards this phenomenon. Social factors like political view, multicultural environment (homeland), education level, and demographic factors like gender are supposedly accepted to have effective on multicultural attitudes of people. Given that all participants have the same education level (university students), the other factors were chosen to understand their effect on multiculturalism attitude.

As a non-EU country, Turkey hosting over 4 million refugees and trying to be a EU member, Austria which has been a EU member for 14 years and has many foreign students, and Hungary which has been a EU member are targeted because it is believed that they all have different agenda for multicultural issues in an era when migration flux is at its peak.

Austrian university students have the highest total score of multicultural attitude and know sub dimension while Turkish university students have the highest scores of care and act sub-dimensions. The most striking conclusion of the study is that living/studying in an EU member country does not necessarily mean that university students have a high level of multicultural attitude. University students from Turkey at this point has a higher level of multicultural level than Hungarian ones and their overall score are not much less than Austrian ones. These findings may also reveal that rising far right in Europe do not find supporters in Austrian and Hungarian youth (though Hungarian has the lowest among three, their overall score is interpreted "positive" towards multiculturalism). Moreover, the high number of Syrian refugees since 2015 do not trigger anti-immigrant attitudes for Turkish youth. This may be due to Turkish society's habit of living together with different cultures from the past to the present and its willing acceptance of different cultures.

Secondly, political view is found to be a significant determinant for multicultural attitude and expectedly those holding liberal views among Hungarian and Austrian participants have the highest multicultural score while those holding socialism among Turkish participants have the highest multicultural score. What is unexpected about political view is that apolitical university students have the second highest multicultural scores among Turkish and Austrian university students. It can be said that the number of apolitical university students implies that there is a significant number of young people who cannot define themselves within conventional political ideologies. However, their inclination is towards a positive attitude in terms of multiculturalism.

Gender matters for multicultural attitude and women have a better multicultural attitude in countries where gender inequality is still a problem. In other words, women in Turkey and Hungary have a better multicultural attitude compared to men while there is no significance difference between men and 
women in Austria. It can be deduced that women suffering from gender inequality have a better understanding for multiculturalism.

\section{Acknowledgement}

This research was supported by Kastamonu University Scientific Research Projects Coordination Department. Project Number: KÜ-BAP01/2016-31

The summary of this study was presented as two separate papers at the Second Congress of International Eurasian Social Sciences.

\section{References}

Ahmad, P. (2018). The Middle East Refugee Crisis. Syria and Iraq Case. In Migration and Crime (pp. 1543). Palgrave Macmillan, Cham.

Akcaoğlu, M. Ö., \& Arsal, Z. (2018). Adaptation of Multicultural Efficacy Scale to Turkish: A Study of Validity and Reliability. Kastamonu Education Journal, 26(1), 261-270.

Atanasoska, T., \& Proyer, M. (2018). On the brink of education: Experiences of refugees beyond the age of compulsory education in Austria. European Educational Research Journal, 17(2), 271-289.

Austrian Press \& Information Service in the United States. (2017). Results of Austrian Parliamentary Election 2017. Retrieved from https://www.austria.org/the-latest/2017/10/30/austrianparliamentary-election-2017

Aydın, H. (2012). Multiculturalism comes to Turkish classrooms.

Banks, J. A. (2010). Multicultural education: Characteristics and goals In J. A. Banks \& C. A. M. Banks (Eds.), Multicultural education: Issues and perspectives (pp. 1-26). Hoboken: John Wiley \& Sons.

Baron-Cohen, S., \& Wheelwright, S. (2004). The empathy quotient: an investigation of adults with Asperger syndrome or high functioning autism, and normal sex differences. Journal of autism and developmental disorders, 34(2), 163-175.

Barrett, L. F., Lane, R. D., Sechrest, L., \& Schwartz, G. E. (2000). Sex differences in emotional awareness. Personality and Social Psychology Bulletin, 26(9), 1027-1035.

BBC. (2016). Migrant crisis: Austria to slash asylum claims. Retrieved from https://www.bbc.com/news/world-europe-35364768

Berry, J. W., \& Sam, D. L. (2014). Multicultural Societies. In V. Benet-Martínez \& Y. Hong (Eds.), The Oxford handbook of multicultural identity. Oxford: Oxford Library of Psychology.

Bloemraad, I., Korteweg, A., \& Yurdakul, G. (2008). Citizenship and immigration: Multiculturalism, assimilation, and challenges to the nation-state. Annual review of sociology, 34, 153-179.

Breugelmans, S. M., \& Van De Vijver, F. J. (2004). Antecedents and components of majority attitudes toward multiculturalism in the Netherlands. Applied Psychology, 53(3), 400-422.

Briton, N. J., \& Hall, J. A. (1995). Beliefs about female and male nonverbal communication. Sex Roles, 32(1-2), 79-90.

Cartwright, A., Sik, E., \& Svensson, S. (2008). Social capital and the integration of minorities and immigrants in Hungary. Retrieved from Budapest, Hungary:

Clayton, J. (2015). UNHCR chief issues key guidelines for dealing with Europe's refugee crisis. Retrieved from http://www.unhcr.org/55e9793b6.html 
Çoban, A. E., Karaman, N. G., \& Doğan, T. (2010). Öğretmen adaylarının kültürel farklılıklara yönelik bakış açılarının çeşitli demografik değişkenlere göre incelenmesi. Abant Izzet Baysal Üniversitesi Eğitim Fakültesi Dergisi, 10(1), 125-131.

Damgacı, F. K., \& Aydın, H. (2013). Akademisyenlerin çokkültürlü eğitime ilişkin tutumları. Elektronik Sosyal Bilimler Dergisi, 12(45), 325-341.

Davis, M. H. (2018). Empathy: A social psychological approach: Routledge.

Demir, S. (2012). Çok kültürlü eğitimin Erciyes Üniversitesi öğretim elemanları için önem derecesi. Electronic Turkish Studies, 7(4), 1453-1475.

Deutsche Welle. (2017). Austria plans tougher measures against refused asylum seekers. Retrieved from https://www.dw.com/en/austria-plans-tougher-measures-against-refused-asylum-seekers/a$\underline{37750857}$

Enger, K., \& Lajimodiere, D. (2011). A multi-cultural transformative approach to learning: Assessing attitude change in doctoral students following an online diversity course. Multicultural Education, 5(3), 176-193.

European Commission. (2018). Future of Europe (including "climate change"). Retrieved from http://ec.europa.eu/commfrontoffice/publicopinion/index.cfm/Survey/getSurveyDetail/instruments /SPECIAL/surveyKy/2217

Fürstenau, S., \& Gomolla, M. (2011). Migration und schulischer Wandel: Mehrsprachigkeit. In F. S \& G. M (Eds.), Migration und schulischer Wandel: Mehrsprachigkeit (pp. 13-24). Wiesbaden: VS Verlag für Sozialwissenschaften.

Gökşen, F., Cemalcılar, Z., \& Gürlesel, C. F. (2008). Türkiye'de ilköğretim okullarında okulu terk ve izlenmesi ile önlenmesine yönelik politikalar Retrieved from http://spm.ku.edu.tr/wpcontent/uploads/pdf/okulterk.pdf

Groves, R. M., Fowler Jr, F. J., Couper, M. P., Lepkowski, J. M., Singer, E., \& Tourangeau, R. (2011). Survey methodology: John Wiley \& Sons.

Harles, J. C. (1997). Integration before assimilation: Immigration, multiculturalism and the Canadian polity. Canadian Journal of Political Science/Revue canadienne de science politique, 30(4), 711-736.

Heywood, A. (2013). Siyasi ideolojiler. Ankara: Adres Yayınları.

Hofer, K., Skrivanek, I., \& Tomic, M. (2015). Migration und Lehre: Über die Ursachen der unterschiedlichen Nutzung des österreichischen Lehrstellenangebotes: ÖGB Verlag.

Inglehart, R. F., \& Norris, P. (2016). Trump, Brexit, and the rise of populism: Economic have-nots and cultural backlash.

Kafkadesk. (2018). Hungary extends "migration state of emergency" despite lack of threat. Retrieved from https://kafkadesk.org/2018/09/06/hungary-extends-migration-state-of-emergency-despitelack-of-threat/

Karácsony, G., \& Róna, D. (2011). The Secret of Jobbik. Reasons behind the rise of the Hungarian radical right. Journal of East European \& Asian Studies, 2(1), 61-92.

Kim, M. (2014). A comparison study on multicultural attitude and relating factors of nursing college students and non-nursing major students in Korea. Journal of the Korea Academia-Industrial cooperation Society, 15(4), 2310-2319.

KONDA Araştırma ve Danışmanlık A.Ş. (2018). 10 yılda gençlerde ne değişti? 2008 - 2018. Retrieved from https://interaktif.konda.com.tr/tr/Gencler2018/\#3rdPage

Krüger-Potratz, M. (2004). Lehrerbildung im zeichen von pluralität und differenz. SozialwissenschaftlicherFachinformationsdienst soFid, 1, 7-16. 
Lesińska, M. (2014). The European backlash against immigration and multiculturalism. Journal of Sociology, 50(1), 37-50.

Marton, K. (2001). In what ways are the Afghans different? In P. Nyíri, J. Tóth, M. Fullerton, (Ed.), Diasporas and Politics (pp. 27-41). Budapest: Centre For Migration And Refugee Studies.

McCray, C. R., \& Beachum, F. D. (2010). An analysis of how the gender and race of school principals influences their perceptions of multicultural education. International Journal of Education Policy and Leadership, 5(4), 1-10.

McCray, C. R., Wright, J. V., \& Beachum, F. D. (2004). An analysis of secondary school principals'perceptions of multicultural education. Education, 125(1), 111-120.

Miller-Whitehead, M. (2005). A comparison of multicultural attitudes by gender, education level, and state of origin. Online Submission.

Mitchell, B. M., \& Salsbury, R. E. (1996). Multicultural education: An international guide to research, policies, and programs: Greenwood Publishing Group.

Modood, T. (2011). Multiculturalism and integration: Struggling with confusions. H. Mahamdallie, 6176.

Mülteciler Derneği. (2018). Türkiye'deki Suriyeli sayısı. Retrieved from https://multeciler.org.tr/turkiyedeki-suriyeli-sayisi/

Munroe, A., \& Pearson, C. (2006). The Munroe multicultural attitude scale questionnaire: A new instrument for multicultural studies. Educational and Psychological Measurement, 66(5), 819-834.

Nadelson, L. S., Boham, M. D., Conlon-Khan, L., Fuentealba, M. J., Hall, C. J., Hoetker, G. A., Moneymaker, K. J. (2012). A shifting paradigm: Preservice teachers' multicultural attitudes and efficacy. Urban Education, 47(6), 1183-1208.

OECD. (2019a). OECD Data: Indicators for Austria. Retrieved from https://data.oecd.org/austria.htm

OECD. (2019b). Share of international, foreign and all students enrolled by field of education. Retrieved from https://stats.oecd.org/Index.aspx?DataSetCode=EAG ENRL MOBILES FIELDS\#

OECD. (2019c). Youth unemployment rate. Retrieved from https://data.oecd.org/unemp/youthunemployment-rate.htm

Özdemir, M., \& Dil, K. (2013). Öğretmenlerin çokkültürlü eğitime yönelik tutumları: Çankırı ili örneği. Ankara Üniversitesi Eğitim Bilimleri Fakültesi Dergisi, 46(2), 215-232.

Pettus, A. M., \& Allain, V. A. (1999). Using a questionnaire to assess prospective teachers' attitudes toward multicultural education issues. Education, 119(4), 651-651.

Polat, S., \& Barka, T. O. (2012). Multiculturalism and intercultural education: A comparative study with a sample of Swiss and Turkish candidate teachers. World Applied Sciences Journal, 18(9), 1180-1189.

Queen's University. (2011). Multiculturalism policies in contemporary democracies. Retrieved from https://www.queensu.ca/mcp/immigrant-minorities/evidence/austria

Robinson, M. D., \& Johnson, J. T. (1997). Is it emotion or is it stress? Gender stereotypes and the perception of subjective experience. Sex Roles, 36(3-4), 235-258.

Schalk-Soekar, S. R., \& Van de Vijver, F. J. (2008). The concept of multiculturalism: A study among Dutch majority members. Journal of Applied Social Psychology, 38(8), 2152-2178.

Spinthourakis, J. A., Lalor, J., \& Berg, W. (2011a). Cultural diversity in the classroom: A european comparison: Springer Science \& Business Media.

Spinthourakis, J. A., Lalor, J., \& Berg, W. (2011b). Preface. In J. A. Spinthourakis, J. Lalor, \& W. Berg (Eds.), Cultural diversity in the classroom: A European comparison. Germany: VS Research. 
Sprague-Jones, J. (2011). Extreme right-wing vote and support for multiculturalism in Europe. Ethnic and Racial Studies, 34(4), 535-555.

Szegö, P. (2019). Fidesz-KDNP wins landslide victory in Sunday's general election. The Budapest Beacon. Retrieved from https://budapestbeacon.com/fidesz-kdnp-wins-landslide-victory-in-sundaysgeneral-election/

Taşkın, Y. (Ed.) (2014). Siyaset kavramlar, kurumlar, süreçler İstanbul: Iletişim Yayınları.

Thorpe, N. (2015). Migrant crisis: Hungary denies fuelling intolerance in media. Retrieved from https://www.bbc.com/news/world-europe-35162515

Timmers, M., Fischer, A., \& Manstead, A. (2003). Ability versus vulnerability: Beliefs about men's and women's emotional behaviour. Cognition and emotion, 17(1), 41-63.

Tinkler, B., Hannah, C. L., Tinkler, A., \& Miller, E. (2014). Analyzing a service-learning experience using a social justice lens. Teaching Education, 25(1), 82-98.

Trotman, C. J. (2002). Multiculturalism: Roots and realities. Bloomington \& Indianapolis: Indiana University Press.

Turan, E. (2017). Siyaset. Konya: Palet Yayınları.

Turner, M. M. (2007). Multicultural teacher attitudes and cultural sensitivity: An initial exploration of the experiences of individuals in a unique alternative teacher certification program. Master's Thesis. University of Notre Dame. Notre Dame, IN.

UNESCO Institute for Statistics. (2019). Global flow of tertiary-level students. Retrieved from http://uis.unesco.org/en/uis-student-flow

UNHCR. (2018). Population statistics. Retrieved from http://popstats.unhcr.org/en/demographics

Unicef Türkiye Milli Komitesi. (2018). Türkiye'deki Suriyeli çocuklar. Retrieved from https://www.unicefturk.org/yazi/acil-durum-turkiyedeki-suriyeli-cocuklar

United Nations. (2018). Gender inequality index. Retrieved from http://hdr.undp.org/en/composite/GII

Ünlü, İ., \& Örten, H. (2013). Öğretmen adaylarının çokkültürlülük ve çokkültürlü eğitime yönelik algılarının incelenmesi. Dicle Üniversitesi Ziya Gökalp Eğitim Fakültesi Dergisi, 21(2013), 287-302.

Uttley, C. M. (2008). Multicultural awareness in college freshmen: An examination of measures and interventions. (Doctoral Dissertation), University of Rhode Island Rhode Island

Verloo, M. (2006). Multiple inequalities, intersectionality and the European Union. European Journal of Women's Studies, 13(3), 211-228.

Weiler, L. M., Helfrich, C. M., Palermo, F., \& Zimmerman, T. S. (2013). Exploring diversity attitudes of youth placed in residential treatment facilities. Residential Treatment For Children \& Youth, 30(1), 2339.

Zaslove, A. (2004). Closing the door? The ideology and impact of radical right populism on immigration policy in Austria and Italy. Journal of Political Ideologies, 9(1), 99-118.

Zemni, S., \& Parker, C. (2002). European union, Islam \& the challenges of multiculturalism rethinking the problematique. In S. T. Hunter (Ed.), Islam in Europe: The New Social, Cultural, and Political Landscape (pp. 231-244). Washington: Praeger Publ. 